\title{
Short communication: Immediate and deferred milk production responses to concentrate supplements in cows grazing fresh pasture
}

\author{
J. R. Roche, ${ }^{* 1}$ J. K. Kay, ${ }^{*}$ A. G. Rius, ${ }^{*}$ T. M. Grala, ${ }^{*}$ A. J. Sheahan, ${ }^{*}$ H. M. White, $\dagger^{2}$ and C. V. C. Phyn ${ }^{*}$ \\ *DairyNZ Ltd., Hamilton, New Zealand 3240 \\ †Purdue University, West Lafayette, IN 47907-2053
}

\begin{abstract}
The objective of this study was to determine the increase in milk production from supplementation that occurred after supplementation ceased. This portion of the total response (i.e., the deferred response), although accepted, is generally not accounted for in short-term component research projects, but it is important in determining the economic impact of supplementary feeding. Fifty-nine multiparous Holstein-Friesian dairy cows were offered a generous allowance of spring pasture $[>45 \mathrm{~kg}$ of dry matter $(\mathrm{DM}) / \mathrm{cow}$ per day) and were supplemented with 0,3 , or $6 \mathrm{~kg}(\mathrm{DM}) / \mathrm{d}$ of pelleted concentrate (half of the allowance at each milking event) in a complete randomized design. Treatments were imposed for the first $12 \mathrm{wk}$ of lactation. Treatments were balanced for cow age $(5.4 \pm 1.68 \mathrm{yr})$, calving date (July $27 \pm 26.0 \mathrm{~d}$ ), and genetic merit for milk component yield. During the period of supplementation, milk yield and the yield of milk components increased (1.19 $\mathrm{kg}$ of milk, $0.032 \mathrm{~kg}$ of fat, $0.048 \mathrm{~kg}$ of protein, and $0.058 \mathrm{~kg}$ of lactose $/ \mathrm{kg}$ of concentrate DM consumed), but neither body condition score nor body weight was affected. After concentrate supplementation ceased and cows returned to a common diet of fresh pasture, milk and milk component yields remained greater for $3 \mathrm{wk}$ in the cows previously supplemented. During this 3 -wk period, cows that previously received 3 and $6 \mathrm{~kg}$ of concentrate DM per day produced an additional 2.3 and $4.5 \mathrm{~kg}$ of milk/d, 0.10 and $0.14 \mathrm{~kg}$ of fat $/ \mathrm{d}, 0.10$ and $0.14 \mathrm{~kg}$ of protein $/ \mathrm{d}$, and 0.10 and $0.19 \mathrm{~kg}$ of lactose $/ \mathrm{d}$, respectively, relative to unsupplemented cows. This is equivalent to an additional $0.19 \mathrm{~kg}$ of milk, $0.006 \mathrm{~kg}$ of fat, $0.006 \mathrm{~kg}$ of protein, and $0.008 \mathrm{~kg}$ of lactose per $1 \mathrm{~kg}$ of concentrate DM previously consumed, which would not be accounted for in the immediate response. As a result of this deferred response to supplements, the total milk production benefit to concentrate supple-
\end{abstract}

\footnotetext{
Received June 15, 2011.

Accepted December 18, 2012.

${ }^{1}$ Corresponding author: john.roche@dairynz.co.nz

${ }^{2}$ Current address: Department of Animal Science, University of Connecticut, Storrs 06269-4004.
}

ments is between $7 \%$ (lactose yield) and $32 \%$ (fat yield) greater than the marginal response measured during the component experiment. Recommendations to dairy producers based on component feeding studies must be revised to include this deferred response.

Key words: milk production, body condition score, supplement

\section{Short Communication}

In seasonal calving systems based on grazed pasture, cow DMI demand is matched with the profile of pasture supply through alterations in stocking rate (Macdonald et al., 2008) and calving date (Dillon et al., 1995). However, the rate of increase in pasture DM growth in spring tends to be more rapid than the increase in herd DMI demand (Dillon et al., 2005; Roche et al., 2009a); therefore, to coordinate maximum herd demand with pasture supply, management systems ensure that calving occurs before sufficient pasture is available to feed the cows fully (Dillon et al., 1995; Roche et al., 2009b). In addition, pasture-based production systems are subject to climatic variations, with pasture availability dependent on temperature and precipitation (Roche et al., 2009a). Where cow requirements are not met by pasture availability, supplements can be offered to ensure that cows are not underfed (Bargo et al., 2003). In determining the profitability of this, it is necessary to be able to predict the total response to supplements.

In a comprehensive review of the literature, Bargo et al. (2003) concluded that, on average, grazing cows produce $1 \mathrm{~kg}$ of milk for $1 \mathrm{~kg}$ of concentrate DM consumed. Responses are less than theoretically possible because cows reduce their DMI of pasture (substitution: Stockdale, 2000; Bargo et al., 2003; Sheahan et al., 2011) concurrently when offered supplements and because fiber digestion declines with the inclusion of starch in the ration (Bargo et al., 2003; Doyle et al., 2005; Nousiainen et al., 2009). However, the majority of the studies reviewed were part-lactation experiments, with responses reported only for the period of supplementation; deferred production responses (i.e., effect of supplements beyond the experimental period) were not 
determined. In comparison, in whole-lactation studies, in which supplements are used as necessary, it is not possible to determine the deferred effect of supplement input at any one time because of other confounding effects of treatment. Studies by Kennedy et al. (2007) and McEvoy et al. (2008) indicate that feeding concentrates during early lactation results in both immediate and deferred effects on milk production; however, the relationships between timing, degree, and duration of supplementation on the deferred response remain unclear.

Nutrition is known to influence mammary cell number, secretory activity, or both (Capuco et al., 2001; Akers, 2002; Nørgaard et al., 2005). It is plausible, therefore, that supplementing grazing dairy cows with concentrates would have effects beyond the period of supplementation. Consistent with this, an anecdotal " 1 in 200" rule (Hutjens, 2003) implies that every $1 \mathrm{~kg}$ of milk secreted at peak production will result in approximately $200 \mathrm{~kg}$ of milk subsequent to peak (i.e., $1 \mathrm{~kg}$ of milk for every additional day of lactation), suggesting that supplementation in early lactation could have far larger effects than those reported by Bargo et al. (2003) or Stockdale (2000). Van Soest (1982) hypothesized such an effect when he suggested long-term effects of early-lactation management strategies on the shape of the lactation curve. The lactation profiles of milk and milk component yields reported by Roche et al. (2006) are consistent with such an effect, but it was not possible to separate the effect of historical versus current nutrition in that study. Therefore, data generated in a previous experiment (Grala et al., 2011) and milk production data collected routinely subsequent to the completion of that experiment were used to quantify the immediate, deferred, and total effect of concentrate supplementation offered to cows grazing a generous allowance of fresh pasture in early lactation.

The experiment was conducted at Lye Farm (DairyNZ, Hamilton, New Zealand; $37^{\circ} 46^{\prime} \mathrm{S} 175^{\circ} 18^{\prime} \mathrm{E}$ ) and experimental details were reported by Grala et al. (2011). All treatments and measurements were approved by the Ruakura Animal Ethics Committee (Hamilton, New Zealand). Fifty-nine multiparous Holstein-Friesian dairy cows were allocated to 1 of 3 feeding treatments in a completely randomized design. Treatments were imposed for the first 12 wk of lactation. Treatments were as follows: no concentrate supplementation $(\mathbf{C 0}: \mathrm{n}$ $=19), 3 \mathrm{~kg}(\mathrm{DM})$ of concentrates/d $($ C3: $\mathrm{n}=20)$, or 6 $\mathrm{kg}(\mathrm{DM})$ of concentrates/d $(\mathbf{C 6}: \mathrm{n}=20)$. Treatments were balanced for cow age $(5.4 \pm 1.68 \mathrm{yr})$, calving date (July $27 \pm 26.0 \mathrm{~d}$ ), and genetic merit for milk component yield. After $12 \mathrm{wk}$ of supplementation, all cows were managed in a manner similar to that described by Macdonald et al. (2008).
All cows were rotationally grazed as one herd for the duration of the experiment and were provided with a generous allowance of fresh pasture $(>45 \mathrm{~kg}$ of DM/ cow per d, measured to ground level). Pasture allowance was sufficient to ensure unrestricted DMI (up to approximately $25 \mathrm{~kg}$ of $\mathrm{DM} / \mathrm{d}$ ) of fresh pasture in nonsupplemented cows. Cows had access to a fresh allocation of high-quality pasture daily throughout the experimental period $(\mathrm{CP}=22.4 \pm 2.64 \% \mathrm{DM}$; OM digestibility $=82.6 \pm 1.42 \% \mathrm{DM} ; \mathrm{NDF}=48.3 \pm 4.91 \%$ $\mathrm{DM} ; \mathrm{ADF}=22.5 \pm 1.54 \% \mathrm{DM} ;$ lipid $=4.3 \pm 0.12 \%$ $\mathrm{DM} ; \mathrm{NSC}=15.7 \pm 3.94 \% \mathrm{DM} ; \mathrm{ME}=12.4 \pm 0.40$ $\mathrm{MJ} / \mathrm{kg}$ of DM). Concentrates (32\% crushed barley, $60 \%$ crushed corn, $2 \%$ wheat middlings, $6 \%$ molasses; $\mathrm{CP}=$ $12.9 \pm 3.04 \% \mathrm{DM} ; \mathrm{NDF}=11.5 \pm 1.49 \% \mathrm{DM}$; lipid $=$ $2.8 \pm 0.25 \% \mathrm{DM} ; \mathrm{NSC}=65.1 \pm 2.12 \% \mathrm{DM}$ ) were offered individually in 2 equal allowances during milking.

Representative samples of pasture were collected daily by plucking pasture to grazing height from paddocks due to be grazed to simulate pasture selected by the cows. Samples were bulked weekly and analyzed for $\mathrm{CP}, \mathrm{NDF}$, ADF, soluble sugars, fat, ash, and OM digestibility by near infrared spectroscopy (Corson et al., 1999). The ME was derived directly from predicted OM digestibility, based on an in vitro cellulose digestibility assay (Roughan and Hollan, 1977), which was calibrated against in vivo standards (Corson et al., 1999).

Individual milk yields were recorded daily (GEA Farm Technologies, Oelde, Germany). Milk fat, CP, and lactose concentrations were determined by Milkoscan (Foss Electric, Hillerød, Denmark) on individual morning and afternoon aliquot samples collected on $1 \mathrm{~d} / \mathrm{wk}$. Milk $\mathrm{NE}_{\mathrm{L}}$ and 4\% FCM were calculated (NRC, 2001) as follows:

$$
\begin{aligned}
& \mathrm{NE}_{\mathrm{L}}(\mathrm{MJ} / \mathrm{kg})=4.186 \times[(0.0929 \times \text { fat \% }) \\
& +(0.0547 \times \mathrm{CP} \%)+(0.0395 \times \text { lactose \% })]
\end{aligned}
$$

$4 \% \mathrm{FCM}=(0.4 \times \mathrm{kg}$ of milk $/ \mathrm{d})+(15 \times \mathrm{kg}$ of fat $/ \mathrm{d})$.

Body weight and BCS were determined weekly for the first 12 wk postcalving following the morning milking. Body condition score was assessed on a 10-point scale, where 1 is emaciated and 10 is obese (Roche et al., 2004).

Blood was sampled weekly during the first 12 wk of lactation. A $10-\mathrm{mL}$ evacuated blood tube (140 IU of sodium heparin) was collected from each cow by coccygeal venipuncture before the morning milking (approximately $0730 \mathrm{~h}$ ). Following centrifugation $(1,120 \times$ $g, 12 \mathrm{~min}, 4^{\circ} \mathrm{C}$ ), plasma was aspirated and stored at $-20^{\circ} \mathrm{C}$ until analysis. Analyses for NEFA (colorimetric 
method) and glucose (hexakinase method) were performed on a Hitachi 717 analyzer (Roche, Basel, Switzerland) at $30^{\circ} \mathrm{C}$ by Alpha Scientific Ltd. (Hamilton, New Zealand). Inter- and intraassay CV were $<2 \%$ for NEFA and glucose. Growth hormone (Downing et al., 1995), IGF-1 (Gluckman et al., 1983), insulin (Hales and Randle, 1963), and leptin (Blache et al., 2000) were measured in duplicate by double-antibody RIA with inter- and intraassay $\mathrm{CV}<6 \%$.

Milk production, BCS, BW, and metabolite data were analyzed with a repeated measurement analysis method using the procedure AREPMEASURES in GenStat 8.2 (VSN International, Hemel Hempstead, UK). The means of wk 1 to 12,13 to 43 , and 1 to 43 were calculated for each cow as a summary measure and analyzed using linear models including effects of diet and linear effects of diet as fixed effects, and cow as a random effect.

Lactation profiles and cumulative milk production are presented in Figure 1 and Table 1, respectively. Consistent with the aforementioned reviews of this subject (Stockdale, 2000; Bargo et al., 2003), milk production during the period when cows received supplements (wk 1-12) increased $(P<0.001)$ with supplementation. Milk, 4\% FCM, and ECM yields increased 1.19, 0.97, and $1.07 \mathrm{~kg} / \mathrm{kg}$ of concentrate (DM) supplement consumed, respectively. Although the milk yield response to supplements was greater than the average response rate reported by Bargo et al. (2003), the increase in $4 \%$ FCM and ECM $/ \mathrm{kg}$ DM of supplements is very similar to the conclusions from their review. The production responses are also consistent with other studies using similar cows grazing similar quality pastures (Kennedy et al., 2002; Horan et al., 2005; Sheahan et al., 2011).

Milk composition during wk 1 to 12 was also affected by feed supplementation. Milk protein percentage increased $(P<0.01)$ with increasing amounts of concentrate, but milk fat and lactose percentages were unaffected by treatment. This resulted in an increase $(P<0.001)$ in the protein to fat ratio in milk with increasing concentrate intake and greater $(P<0.05)$ yields of fat, protein, and lactose in supplemented cows $(0.032,0.048$, and $0.058 \mathrm{~kg}$ per $\mathrm{kg}(\mathrm{DM})$ of concentrate supplement consumed, respectively). The increase in milk protein was consistent with the positive effect of concentrate on IGF-1 in the current study (Table 2) and Kay et al. (2009) and in the insulin-mediated increase in milk protein associated with dietary NSC (Sporndly, 1991; Rius et al., 2010). Although provision of NSC would also be expected to increase the intestinal supply of metabolizable protein, this is unlikely to be a significant contributory factor to the increased milk protein, as metabolizable protein was not limiting in these diets.
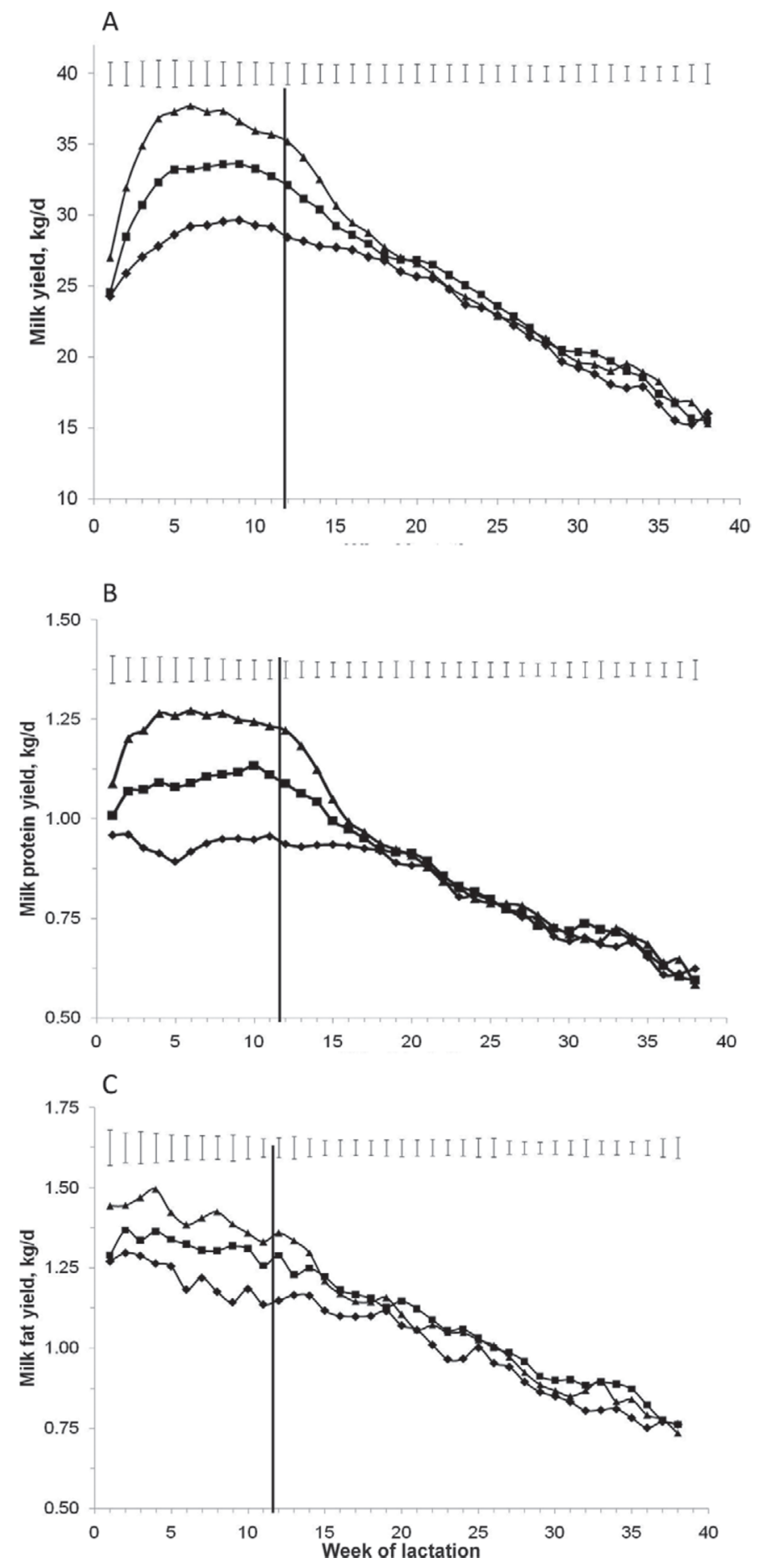

Figure 1. Milk (A), protein (B), and fat (C) production profiles of dairy cows grazing fresh pasture and offered $0(\bullet), 3(\mathbf{\square})$, or $6(\boldsymbol{\Lambda}) \mathrm{kg}$ of concentrates (DM) daily for the first $12 \mathrm{wk}$ of lactation. The vertical line marks the end of the 12-wk supplement feeding period. Error bars represent twice the standard error of the difference.

Neither BW (529, 533, and $537 \mathrm{~kg}$ for $\mathrm{C} 0$, C3, and C6, respectively) nor BCS (4.0, 4.1, and 4.2 for $\mathrm{C} 0$, C3, and C6, respectively) at the end of the period of 
Table 1. Cumulative milk production $(\mathrm{kg})$ over $43 \mathrm{wk}$ from dairy cows grazing fresh pasture and offered 0 (C0), 3 (C3), or 6 (C6) $\mathrm{kg}$ (DM) of concentrates daily for the first 12 wk of lactation

\begin{tabular}{|c|c|c|c|c|c|c|}
\hline \multirow[b]{2}{*}{ Item } & \multirow[b]{2}{*}{ Week } & \multicolumn{3}{|c|}{ Diet } & \multirow[b]{2}{*}{$\mathrm{SED}^{1}$} & \multirow[b]{2}{*}{$P$-value } \\
\hline & & $\mathrm{C} 0$ & C3 & C6 & & \\
\hline \multirow[t]{4}{*}{ Milk } & 1 to 43 & 6,379 & 6,680 & 7,055 & 316.6 & 0.12 \\
\hline & 1 to 12 & 2,368 & 2,668 & 2,966 & 133.7 & $<0.001$ \\
\hline & 13 to 15 & 586 & 635 & 681 & 27.5 & $<0.01$ \\
\hline & 16 to 43 & 3,425 & 3,376 & 3,409 & 234.1 & 0.98 \\
\hline \multirow[t]{4}{*}{$4 \% \mathrm{FCM}^{2}$} & 1 to 43 & 6,651 & 6,962 & 7,231 & 284.7 & 0.14 \\
\hline & 1 to 12 & 2,477 & 2,727 & 2,964 & 130.4 & $<0.01$ \\
\hline & 13 to 15 & 596 & 643 & 676 & 23.1 & $<0.01$ \\
\hline & 16 to 43 & 3,578 & 3,592 & 3,592 & 224.8 & 0.99 \\
\hline \multirow[t]{4}{*}{$\mathrm{ECM}^{3}$} & 1 to 43 & 6,625 & 6,939 & 7,250 & 277.9 & 0.09 \\
\hline & 1 to 12 & 2,442 & 2,720 & 2,982 & 127.6 & $<0.001$ \\
\hline & 13 to 15 & 592 & 642 & 679 & 22.3 & $<0.001$ \\
\hline & 16 to 43 & 3,592 & 3,577 & 3,589 & 224.6 & 0.99 \\
\hline \multirow[t]{4}{*}{ Fat } & 1 to 43 & 273 & 286 & 294 & 12.2 & 0.24 \\
\hline & 1 to 12 & 102 & 111 & 118 & 5.7 & $<0.05$ \\
\hline & 13 to 15 & 24 & 26 & 27 & 1.0 & $<0.05$ \\
\hline & 16 to 43 & 147 & 149 & 149 & 9.4 & 0.97 \\
\hline \multirow[t]{4}{*}{ Protein } & 1 to 43 & 221 & 232 & 247 & 9.4 & $<0.05$ \\
\hline & 1 to 12 & 79 & 92 & 103 & 4.3 & $<0.001$ \\
\hline & 13 to 15 & 20 & 22 & 23 & 0.8 & $<0.001$ \\
\hline & 16 to 43 & 122 & 118 & 120 & 7.8 & 0.88 \\
\hline \multirow[t]{4}{*}{ Lactose } & 1 to 43 & 311 & 326 & 342 & 14.8 & 0.12 \\
\hline & 1 to 12 & 114 & 129 & 143 & 6.4 & $<0.001$ \\
\hline & 13 to 15 & 29 & 31 & 33 & 1.3 & $<0.01$ \\
\hline & 16 to 43 & 168 & 166 & 166 & 11.2 & 0.98 \\
\hline \multirow[t]{4}{*}{ Protein to fat ratio } & 1 to 43 & 0.82 & 0.82 & 0.85 & 0.023 & 0.37 \\
\hline & 1 to 12 & 0.78 & 0.84 & 0.89 & 0.030 & $<0.01$ \\
\hline & 13 to 15 & 0.83 & 0.84 & 0.88 & 0.029 & 0.15 \\
\hline & 16 to 43 & 0.84 & 0.80 & 0.82 & 0.024 & 0.30 \\
\hline
\end{tabular}

${ }^{1}$ Standard error of the difference of the means.

${ }^{2} 4 \% \mathrm{FCM}=(0.4 \times \mathrm{kg}$ of milk $/ \mathrm{d})+(15 \times \mathrm{kg}$ of fat $/ \mathrm{d})$.

${ }^{3} \mathrm{ECM}: \mathrm{NE}_{\mathrm{L}}(\mathrm{MJ} / \mathrm{kg})=4.186 \times[(0.0929 \times$ fat $\%)+(0.0547 \times \mathrm{CP} \%)+(0.0395 \times$ lactose $\%)]$.

supplementation were affected by supplementation in the current study. This is consistent with the previously reported effects of concentrate supplementation in early lactation on BW and BCS (Roche et al., 2006; McCarthy et al., 2007), wherein concentrate input did not affect the rate of BCS or BW loss in early lactation or BCS at 60 DIM, according to McCarthy et al. (2007). Although Roche et al. (2006) did report an effect of early lactation supplementation on nadir BCS, because of a shortening of the period of negative energy balance in supplemented cows, the effect was very small $(\sim 0.02$ BCS units at nadir $/ \mathrm{kg}$ of concentrate DM consumed per day: 5-point BCS scale). Therefore, the lack of a treatment effect on BW and BCS in this study is not surprising. It is also consistent with the lack of effect of concentrate supplementation on lipolysis (Grala et al., 2011) and in the absence of a treatment effect on circulating NEFA and leptin concentrations (Table 2). These results are consistent with those of Kay et al. (2009), who reported no effect of increasing supplemen-

Table 2. Average concentration of circulating metabolites and hormones in dairy cows grazing fresh pasture and offered $0(\mathrm{C} 0), 3(\mathrm{C} 3)$, or $6(\mathrm{C} 6) \mathrm{kg}(\mathrm{DM})$ of concentrates daily for the first $12 \mathrm{wk}$ of lactation

\begin{tabular}{|c|c|c|c|c|c|}
\hline \multirow[b]{2}{*}{ Item } & \multicolumn{3}{|c|}{ Diet } & \multirow[b]{2}{*}{$\mathrm{SED}^{1}$} & \multirow[b]{2}{*}{$P$-value } \\
\hline & $\mathrm{C} 0$ & C3 & C6 & & \\
\hline Glucose, $\mathrm{mmol} / \mathrm{L}$ & 3.2 & 3.4 & 3.4 & 0.06 & $<0.01$ \\
\hline NEFA, mmol/L & 0.46 & 0.47 & 0.51 & 0.042 & 0.44 \\
\hline Growth hormone, $\mathrm{ng} / \mathrm{mL}$ & 3.7 & 2.8 & 2.7 & 0.36 & $<0.01$ \\
\hline IGF-1, ng/mL & 8.8 & 11.0 & 10.8 & 0.87 & $<0.05$ \\
\hline Leptin, ng/mL & 0.76 & 0.81 & 0.81 & 0.053 & 0.44 \\
\hline Insulin, $\mathrm{U} / \mathrm{mL}$ & 1.9 & 2.3 & 2.0 & 0.23 & 0.23 \\
\hline
\end{tabular}

${ }^{1}$ Standard error of the difference of the means. 
tation on plasma NEFA or leptin concentrations during the first $10 \mathrm{wk}$ of lactation.

Concentrate supplementation during the first $12 \mathrm{wk}$ of lactation also resulted in an increase in milk production after supplementation had ceased; however, the effect was transient. Data indicate greater milk, 4\% FCM, and ECM production for $3 \mathrm{wk}$ post-supplementation (a deferred response in wk 13-15: Figure 1 ), with cows producing an additional 2.3 and 4.5, 2.2 and 3.8, and 2.4 and $4.1 \mathrm{~kg} / \mathrm{d}$ in C3 and C6 treatment groups, respectively, compared with cows in $\mathrm{C} 0$; this is equivalent to an additional $0.19,0.16$, and $0.17 \mathrm{~kg} /$ $\mathrm{kg}$ of concentrate (DM) consumed after supplementation had ceased, respectively. Milk composition (\%) between wk 13 and 15 postcalving was not affected by prior supplementation, but because of the increase in milk volume, fat $(P<0.05)$, protein $(P<0.001)$, and lactose $(P<0.01)$ yields during wk 13 to 15 postcalving were greater in cows that had received concentrate supplementation previously. Cows in the C3 and C6 treatment groups produced an additional 0.10 and 0.14 $\mathrm{kg}$ of fat $/ \mathrm{d}, 0.10$ and $0.14 \mathrm{~kg}$ of protein $/ \mathrm{d}$, and 0.10 and $0.19 \mathrm{~kg}$ of lactose/d, respectively, during the $3 \mathrm{wk}$ after supplementation finished. This is equivalent to deferred milk fat, protein, and lactose responses to supplement of $0.006,0.006$, and $0.008 \mathrm{~kg} / \mathrm{kg}$ of concentrate DM consumed, respectively. This is, in part, consistent with the effect of early lactation nutrition described by Van Soest (1982). He summarized the results of earlier studies that suggested that cows underfed in early lactation had a lower milk yield for the remainder of lactation than cows fed well during the same period. No reason was given for such an effect. Although consistent with a deferred effect of superior feeding on milk production, the data presented here do not agree with a lactationlong effect in grazing cows (Figure 1). The temporary nature of the post-supplementation effect of nutrition on milk production was also evident in the work of Delaby et al. (2009), who offered cows diets with high or medium energy density for $14 \mathrm{wk}$ postcalving and then placed half of each group on the alternative treatment's ration. A deferred milk fat and protein yield response was observed for 6 to $8 \mathrm{wk}$, caused by greater milk production in the cows previously fed the high energy density diet. Similarly, Kennedy et al. (2007) and McEvoy et al. (2008) also reported that providing $4 \mathrm{~kg}$ of concentrate DM/d or 3 and $6 \mathrm{~kg}$ of concentrate $\mathrm{DM} / \mathrm{d}$, respectively, during early lactation resulted in increased milk and milk component yields during the 4 -wk period following the end of supplementation. Transient deferred milk responses have also been reported in grazing cows following a severe feed restriction for 5 wk immediately postpartum (Roche, 2007) or 2.5 wk later in early lactation (Burke et al., 2010).
The size and duration of the deferred effects of plane of nutrition are reportedly dependent on the size of the immediate effect (Broster and Broster, 1984), with greater deferred responses associated with conditions where the immediate response is greatest (i.e., when pasture is limiting for an extended period or when the severity of the restriction is greater). However, neither Kennedy et al. (2007) nor McEvoy et al. (2008) detected a significant interaction between pasture allowance and concentrate supplementation level. Further research is required in this area.

The reasons for the deferred increase in milk production beyond the period of supplementation were not determined in the present study. However, several plausible reasons explain this finding. The first 2 possibilities involve an increase in either mammary cell number or secretory cell activity (Capuco et al., 2001; Akers, 2002; Nørgaard et al., 2005). The third involves an increase in pasture DMI in cows that were previously supplemented because of increased hunger associated with their greater milk production when the supplements were removed (Roche et al., 2008). In reality, the temporary post-supplementation effect on milk production is likely a result of all 3 factors, which take some time post-supplementation to reach new equilibriums. Further work is required to understand the physiological basis behind the continued, but temporary, greater milk production post-supplementation in grazing dairy cows.

Our results provide a quantitative assessment of the relative importance of immediate and deferred increases in milk production from concentrate supplementation. These data have implications for establishing the economic value proposition for supplementation of grazing cows. In this study, milk, 4\% FCM, and ECM production increased $(P<0.01)$ by $1.34,1.15$, and $1.24 \mathrm{~kg} / \mathrm{kg}$ of concentrate DM consumed, respectively; the total response to concentrates was, therefore, 13, 19, and $16 \%$ greater in milk, 4\% FCM, and ECM than the response measured during the period of feeding. Similarly, total milk fat $(0.04 \mathrm{~kg} ; P<0.05)$, protein $(0.05 \mathrm{~kg} ; P<$ $0.001)$, and lactose $(0.06 \mathrm{~kg} ; P<0.01)$ yields were 32 , 8 , and $7 \%$ greater, respectively, than the immediate response. These responses are similar to those reported by Horan et al. (2005) for their "high durability" strain of Holstein-Friesian in a multi-lactation farm systems experiment $(1.16 \mathrm{~kg}$ of SCM, $0.046 \mathrm{~kg}$ of fat, and 0.046 $\mathrm{kg}$ of protein per $\mathrm{kg}$ of concentrate DM offered).

The data indicate a deferred response to concentrate supplementation in dairy cows grazing fresh pasture in spring, which, to date, has rarely been quantified in component studies evaluating the effect of concentrates in grazing dairy cows. A positive adjustment factor of 10 to $20 \%$ for milk yield variables, $30 \%$ for milk fat, and 
$10 \%$ for milk protein should be built into management advice for dairy producers, to account for this deferred production response.

\section{ACKNOWLEDGMENTS}

The authors thank and acknowledge the technical assistance of J. Lee and P. Aspin, the statistical expertise of B. Dow, and all the help afforded by DairyNZ Lye Farm staff. This study was funded by New Zealand dairy farmers through DairyNZ Inc. (Hamilton, New Zealand).

\section{REFERENCES}

Akers, R. M. 2002. Lactation and the Mammary Gland. Iowa State University Press, Ames.

Bargo, F., L. D. Muller, E. S. Kolver, and J. E. Delahoy. 2003. Invited review: Production and digestion of supplemented dairy cows on pasture. J. Dairy Sci. 86:1-42.

Blache, D., R. L. Tellam, L. M. Chagas, M. A. Blackberry, P. E. Vercoe, and G. B. Martin. 2000. Level of nutrition affects leptin concentrations in plasma and cerebrospinal fluid in sheep. J. Endocrinol. 165:625-637.

Broster, W. H., and V. J. Broster. 1984. Reviews of the progress of dairy science: Long term effects of plane of nutrition on the performance of dairy cows. J. Dairy Res. 51:149-196.

Burke, C. R., Y. J. Williams, L. Hofmann, J. K. Kay, C. V. C. Phyn, and S. Meier. 2010. Effects of an acute feed restriction at the onset of the seasonal breeding period on reproductive performance and milk production in pasture-grazed dairy cows. J. Dairy Sci. 93:1116-1125.

Capuco, A. V., D. L. Wood, R. Baldwin, K. Mcleod, and M. J. Paape. 2001. Mammary cell number, proliferation, and apoptosis during a bovine lactation: Relation to milk production and effect of bST. J. Dairy Sci. 84:2177-2187.

Corson, D. G., G. C. Waghorn, M. J. Ulyatt, and J. Lee. 1999. Forage analysis and livestock feeding. Proc. N.Z. Grassl. Assoc. 61:127132.

Delaby, L., P. Faverdin, G. Michel, C. Disenhaus, and J. L. Peyraud. 2009. Effect of different feeding strategies on lactation performance of Holstein and Normande dairy cows. Animal 3:891-905.

Dillon, P., S. Crosse, G. Stakelum, and F. Flynn. 1995. The effect of calving date and stocking rate on the performance of springcalving dairy cows. Grass Forage Sci. 50:286-299.

Dillon, P., J. R. Roche, L. Shalloo, and B. Horan. 2005. Optimising financial returns from grazing in temperate pastures. Pages 131-147 in Utilisation of Grazed Grass in Temperate Animal Systems: Proc. Satellite Workshop of the XXth International Grassland Congress, Cork, Ireland. Wageningen Academic Publishers, Wageningen, the Netherlands.

Downing, J. A., J. Joss, P. Connel, and R. J. Scaramuzzi. 1995. Ovulation rate and the concentration of gonadotrophic and metabolic hormones in ewes fed lupin grain. J. Reprod. Fertil. 103:137-145.

Doyle, P. T., S. A. Francis, and C. R. Stockdale. 2005. Associative effects between feeds when concentrate supplements are fed to grazing cows: A review on likely impacts on metabolisable energy supply. Aust. J. Agric. Res. 56:13.15-13.29.

Gluckman, P. D., J. J. Johnson-Barrett, J. H. Butler, B. W. Edgar, and T. R. Gunn. 1983. Studies on insulin-like growth factor-I and -II by specific radioligand assays in umbilical cord blood. Clin. Endocrinol. (Oxf.) 19:405-413.

Grala, T. M., M. C. Lucy, C. V. C. Phyn, A. J. Sheahan, J. M. Lee, and J. R. Roche. 2011. Somatotropic axis and concentrate supplementation in grazing dairy cows of genetically diverse origin. J. Dairy Sci. 94:303-315.
Hales, C. N., and P. J. Randle. 1963. Immunoassay of insulin with insulin-antibody precipitate. Biochem. J. 88:137-146.

Horan, B., P. Dillon, P. Faverdin, L. Delaby, F. Buckley, and M. Rath. 2005. The interaction of strain of Holstein-Friesian cows and pasture-based feed systems on milk yield, body weight, and body condition score. J. Dairy Sci. 88:1231-1243.

Hutjens, M. 2003. The gestation-lactation cycle. Pages 24-30 in Feeding Guide. W. D. Hoards \& Sons, Fort Atkinson, WI.

Kay, J. K., C. V. C. Phyn, J. R. Roche, and E. S. Kolver. 2009. Extending lactation in pasture-based dairy cows. II: Effect of genetic strain and diet on plasma hormone and metabolite concentrations. J. Dairy Sci. 92:3704-3713.

Kennedy, E., M. O'Donovan, F. P. O'Mara, J. P. Murphy, and L. Delaby. 2007. The effect of early-lactation feeding strategy on the lactation performance of spring-calving dairy cows. J. Dairy Sci. 90:3060-3070.

Kennedy, J., P. Dillon, P. Faverdin, L. Delaby, F. Buckley, and M. Rath. 2002. The influence of cow genetic merit for milk production on response to level of concentrate supplementation in a grass based system. Anim. Sci. 75:433-445.

Macdonald, K. A., J. W. Penno, J. A. S. Lancaster, and J. R. Roche. 2008. Effect of stocking rate on pasture production, milk production and reproduction of dairy cows in pasture-based systems. J. Dairy Sci. 91:2151-2163.

McCarthy, S., D. P. Berry, P. Dillon, M. Rath, and B. Horan. 2007. Influence of Holstein-Friesian strain and feed system on bodyweight and body condition score lactation profiles. J. Dairy Sci. 90:1859-1869.

McEvoy, M., E. Kennedy, J. P. Murphy, T. M. Boland, L. Delaby, and M. O'Donovan. 2008. The effect of herbage allowance and concentrate supplementation on milk production performance and dry matter intake of spring-calving dairy cows in early lactation. J. Dairy Sci. 91:1258-1269.

Nørgaard, J., A. Sorensen, M. T. Sørensen, J. B. Andersen, and K. Sejrsen. 2005. Mammary cell turnover and enzyme activity in dairy cows: Effects of milking frequency and diet energy density. J. Dairy Sci. 88:975-982.

Nousiainen, J., M. Rinne, and P. Huhtanen. 2009. A meta-analysis of feed digestion in dairy cows. 1 . The effects of forage and concentrate factors on total diet digestibility. J. Dairy Sci. 92:5019-5030.

NRC. 2001. Nutrient Requirements of Dairy Cattle. 7th rev. ed. National Academy Press, Washington, DC.

Rius, A. G., J. A. D. R. N. Appuhamy, J. Cyriac, D. Kirovski, O. Becvar, J. Escobar, M. L. McGilliard, B. J. Bequette, R. M. Akers, and M. D. Hanigan. 2010. Regulation of protein synthesis in mammary glands of lactating dairy cows by starch and amino acids. J. Dairy Sci. 93:3114-3127.

Roche, J. R. 2007. Milk production responses to pre- and post-calving dry matter intake in grazing dairy cows. Livest. Sci. 110:12-24.

Roche, J. R., D. P. Berry, and E. S. Kolver. 2006. Holstein-Friesian strain and feed effects on milk production, body weight, and body condition score profiles in grazing dairy cows. J. Dairy Sci. 89:3532-3543.

Roche, J. R., D. Blache, J. K. Kay, D. R. Miller, A. J. Sheahan, and D. W. Miller. 2008. Neuroendocrine and physiological regulation of intake, with particular reference to domesticated ruminant animals. Nutr. Res. Rev. 21:207-234.

Roche, J. R., P. G. Dillon, C. R. Stockdale, L. H. Baumgard, and M. J. VanBaale. 2004. Relationships among international body condition scoring systems. J. Dairy Sci. 87:3076-3079.

Roche, J. R., L. R. Turner, J. M. Lee, D. C. Edmeades, D. J. Donaghy, K. A. Macdonald, J. W. Penno, and D. P. Berry. 2009a. Weather, herbage quality and milk production in pastoral systems. 3. Interrelationships and associations between climatic variables and herbage growth rate, quality and mineral content. Anim. Prod. Sci. $49: 211-221$

Roche, J. R., L. R. Turner, J. M. Lee, D. C. Edmeades, D. J. Donaghy, K. A. Macdonald, J. W. Penno, and D. P. Berry. 2009b. Weather, herbage quality and milk production in pastoral systems. 4. Effects on dairy cattle production. Anim. Prod. Sci. 49:222-232. 
Roughan, G. P., and R. Hollan. 1977. Predicting in vivo digestibilities of herbage by exhaustive enzymatic hydrolysis of cell walls. J. Sci. Food Agric. 28:1057-1064.

Sheahan, A. J., E. S. Kolver, and J. R. Roche. 2011. Genetic strain and diet effects on grazing behavior, pasture intake and milk production. J. Dairy Sci. 94:3583-3591.

Sporndly, E. 1991. Supplementation of dairy cows offered freshly cut herbage ad libitum with starchy concentrates based on barley or fibrous concentrates based on unmolassed sugar beet pulp and wheat bran. Swedish J. Agric. Res. 21:131-139.

Stockdale, C. R. 2000. Levels of pasture substitution when concentrates are fed to grazing dairy cows in northern Victoria. Aust. J. Exp. Agric. 40:913-921.

Van Soest, P. J. 1982. Energy balance. Pages 385-401 in Nutritional Ecology of the Ruminant. Cornell University Press, Ithaca, NY. 